\title{
Dispersal of Emerald Ash Borer within an Intensively Managed Quarantine Zone
}

\author{
Chris Sargent, Michael Raupp, Dick Bean, and Alan J. Sawyer
}

\begin{abstract}
Emerald ash borer (EAB) (Agrilus planipennis) is one of the most destructive insect pests of urban trees in the United States. The objective of the current study was to determine the rate of spread of $\mathrm{EAB}$ in a quarantine zone where aggressive intervention tactics such as tree destruction occurred. Historical records were examined from the Maryland Department of Agriculture for the years 2003, 2006, 2007, and 2008, to determine the rate of spread of EAB in Maryland, U.S., within the quarantine zone. Despite attempts at eradication and public education, EAB persisted, and the leading edge of beetles moved away from the central infestation point at an average annual rate of $1 \mathrm{~km}$ per year and a maximum annual rate of $1.37 \mathrm{~km}$ per year between 2003 and 2008 . This paper discusses the relative merits and limitations of this quarantine and eradication program and makes suggestions for future management of EAB. Key Words. Agrilus planipennis; dispersal; emerald ash borer; eradication; quarantine; rate of spread.
\end{abstract}

Emerald ash borer (EAB) (Agrilus planipennis), an invasive wood-boring beetle from Asia, was first detected in Michigan, U.S., in 2002. At the time of this writing, the serious pest has destroyed tens of millions of ash trees in thirteen states in the U.S. and two provinces in Canada. Emerald ash borer is a major threat to the sustainability of urban forests in North America (Cappaert et al. 2005; Raupp et al. 2006; Ghandi and Herms in press). Accurate knowledge of the rate of spread of EAB is imperative to help municipalities plan effective management strategies for this devastating pest (Smitley et al. 2008; Ghandi and Herms in press).

Several approaches have been employed to estimate dispersal of EAB. One involved the use of tethered beetles in computermonitored flight mills (Taylor et al. 2005; Taylor et al. 2007). Taylor et al. (2005) determined that mated female beetles flew farther than males, and the average distance flown by females in 24 hours was $1.7 \mathrm{~km}$. A subsequent study confirmed the superior dispersal ability of females, but estimated a maximum flight distance for EAB over several days to be $9.8 \mathrm{~km}$ (Taylor et al. 2007).

Other approaches to estimating dispersal of EAB include direct observations of movement of the beetle from a point of release to a point of capture, or through reconstructing patterns of movement using historical records of beetle infestations and their damage. Haack and Petrice (2004) recorded dispersal of EAB from a central release point to trap logs placed at fixed distances away from the point of release. Beetles were recovered at distances of $250 \mathrm{~m}$ and $1500 \mathrm{~m}$, at two different release sites. McCullough et al. (2004) felled and examined trees surrounding a woodpile heavily infested with EAB. Approximately $70 \%$ of galleries were found in trees within $100 \mathrm{~m}$ of the woodpile, but one gallery was detected $750 \mathrm{~m}$ from the source. In a study that combined tree surveys and examination of felled ash trees, Smitley et al. (2008) determined that EAB infestation caused thinning of ash canopies. They sampled a large number of ashes radiat- ing away from Canton, Michigan, the site at the epicenter of a regional EAB infestation. Smitley et al. (2008) determined the rate of spread of canopy thinning associated with EAB to be 10.6 $\mathrm{km}$ per year. Siegert et al. (2008) used dendrochronological reconstruction and historical records to estimate the rate of spread of EAB in southern Michigan. They concluded that the spread of EAB from a historical epicenter was biphasic with a slow, early phase of about $6.5 \mathrm{~km}$ per year followed by the formation of satellite colonies about $20 \mathrm{~km}$ distant to the core infestation.

Many of the before mentioned studies occurred in federal quarantine zones, under a wide variety of management approaches ranging from minimal intervention, such as limiting the movement of wood and wood products, to more aggressive tactics, including insecticide applications and removal of infested and uninfested trees. The introduction of emerald ash borer to Maryland via an illegal shipment of infested nursery stock from Michigan provided a unique opportunity to study dispersal of this pest within well-defined spatial and temporal dimensions in an area subjected to a federal quarantine and an aggressive eradication program. In April 2003, a nursery in southern Prince George's County, MD, received a shipment of green ash (Fraxinus pennsylvanica) trees. A nursery inspector from the Maryland Department of Agriculture (MDA) noticed unusual exit holes on ashes in the nursery in August 2003, and the USDA Systematic Entomology Laboratory in Beltsville subsequently confirmed the EAB infestation.

Of the original 121 trees shipped from Michigan, 119 were recovered either on site at the nursery, or at landscape sites through trace backs of sales. Ninety-six trees from Michigan still on site at the nursery were destroyed in September 2003, and 23 trees that were installed in landscapes were retrieved and destroyed. An additional 442 ash trees in the nursery from sources other than Michigan were removed and debarked to determine infestation. Seventyone trees were found to be infested with a total of 303 larvae. The 
MDA established a $0.8 \mathrm{~km}$ buffer zone around the nursery and all ash trees within this zone were removed and destroyed by March 2004. From 2004 to 2006, MDA established and monitored 300 trap trees and initiated surveys to locate ashes in the quarantine area. In May 2004, EAB was detected at two landscape sites, but rapid destruction of the trees and intensive re-inspection of remaining trees revealed no further signs of activity. An aggressive public education campaign and subsequent follow-up by MDA staff on hundreds of homeowner calls and site visits throughout central Maryland resulted in no additional detections of EAB. The absence of further detections of EAB in 2004 and lack of detections in 2005 fueled hopes that EAB was eradicated in Maryland.

In August 2006, EAB was detected in a trap tree planted near the nursery and on a girdled native tree outside the eradication zone where trees were removed, but still within the federal quarantine zone. These events initiated an intense, expanded survey that resulted in additional new detections. It was assumed the new detections dated from the initial infestation in 2003 and the eradication zone was expanded $2.4 \mathrm{~km}$ at that time to account for potential movement of the pest over the previous three years. Between 2006 and 2008 thousands of new EAB detections were made, as evidenced by exit holes and active galleries in debarked trees, and by 2008 more than 40,000 ash trees had been removed on more than $73 \mathrm{~km}^{2}$ in Prince George's County. On August 18, 2008, EAB were detected in Charles County, more than $7.24 \mathrm{~km}$ south of the original infestation site in Prince George's County.

The objective of this research was to determine the rate of spread of EAB in a quarantine zone where aggressive intervention tactics, including destruction of infested and uninfested hosts, extensive surveillance, and public education limited the dispersal of this pest. Our overarching goal is to help arborists and urban foresters understand the rate of spread of EAB and provide empirical information to help them develop plans to deal with the management of this pest.

\section{MATERIALS AND METHODS}

Under the guidance of the National EAB Science Panel, a methodology for survey and recordkeeping was established for quarantine and eradication programs in Maryland. The 2003 infestation at the nursery in southern Prince George's County served as the center of the EAB infestation in Maryland. Using Geographic Information System (GIS), a map was generated for a project area $8.05 \mathrm{~km}$ square subdivided into $0.01 \mathrm{~km}^{2}$ plots with the nursery at the center. Distances for all EAB detections were made from a point in the Maryland nursery centrally located between the two blocks of Michigan ash trees to the center of the 0.01 $\mathrm{km}^{2}$ grid cell within which the initial infestation was detected.

Thousands of EAB were detected from 2006-2008. Sometimes clusters of trees with EAB larvae or exit holes were concentrated in an area and sometimes detections occurred in a single, isolated tree. Each year four distinct sample grid cells were selected at the leading edge of the beetle's distribution to be included in the analysis. Each sample grid cell, hereafter called foci, represented a distinct tree or group of trees separated from other foci by several grid cells surveyed during the same year that yielded no EAB detections through debarking both sentinel trees and $10 \%$ of native trees within a $0.8 \mathrm{~km}$ buffer zone outside the eradication zone, and the absence of adult beetles on purple sticky traps. Foci selected for analysis in each year were those most distant from the epicenter irrespective of direction.
Examination of the detection points in 2006 revealed four distinct foci (Figure 1). One focus consisted of a single street tree NNW of the epicenter. A second focus was a single native tree located northwest of the epicenter. The third focus was a single native ash northeast of the epicenter and the last focus consisted of hundreds of native and managed ashes southeast of the epicenter. In 2007, three new foci were detected and one existing focus included in 2006 expanded outward to adjacent grid cells. A focus of several native trees was detected north of the epicenter (Figure 1). A single native tree was detected southwest of the epicenter. Approximately 20 infested native trees were detected west of the epicenter, and the large focus detected southeast of the epicenter in 2006 expanded farther southeast in 2007. In 2008, four new foci were detected (Figure 1). Nearly five miles south of the epicenter, dozens of infested native trees were detected. This detection expanded the eradication zone from Prince George's County to include Charles County, MD. Southeast of the epicenter, a single native tree was detected and southwest of the epicenter two native trees were detected. In late December 2008, a single street tree northwest of the epicenter was confirmed to be infested.

To determine the average rate of advancement of the leading edge, the study authors regressed the distances of the 12 foci (four foci for each of three years) from the nursery against time (years), from the first detection in 2003. The slope of the relationship between distance and time represents the average rate of spread of emerald ash borer in kilometers per year. To estimate a maximum rate of spread for $\mathrm{EAB}$, the distance of the furthest

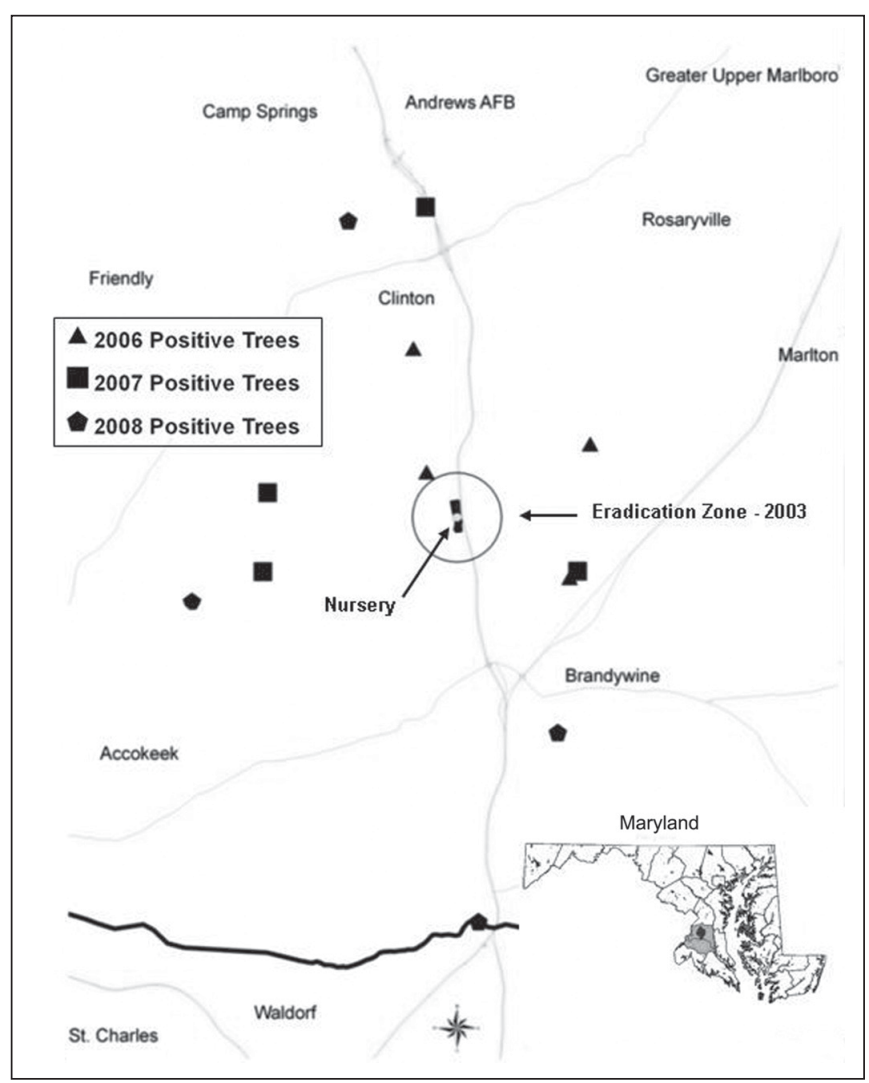

Figure 1. Map of Maryland EAB Project detections from 2003 to 2008, showing epicenter at nursery surrounded by initial 2003 eradication zone, and the four most distant emerald ash borer detections each year in 2006, 2007, and 2008. 
detection was regressed (one focus for each of three years) from the nursery each year against time (year). The slope of this relationship represents the maximum detectable spread of EAB from the current study's data. Regression analyses were performed using the linear regressions procedure of Systat 11 (Systat 2004).

\section{RESULTS AND DISCUSSION}

There was a highly significant positive relationship between the distance of the leading edge of EAB advancement from a central location and the time since the initial introduction of the beetle in Maryland $\left(\mathrm{F}_{1,11}=128.06, P<0.001\right)$. The linear relationship $\mathrm{y}=$ $1.00 \mathrm{x}$, where $\mathrm{y}$ equals distance from the nursery in $\mathrm{km}$ and $\mathrm{x}$ equals time since the initial detection explained approximately $92 \%$ of the variation in the data (Figure 2). Similarly, the maximum dispersal distance was positively related to time $\left(\mathrm{F}_{1,2}=144.64, P<0.007\right)$ $(\mathrm{y}=1.37 \mathrm{x})$ (Figure 2). The regression of maximum distance on time explained approximately $98 \%$ of the variation in the data. In the intensively managed quarantine zone in Maryland, the leading edge of EAB moved on average about $1 \mathrm{~km}$ each year and the furthest dispersers traveled about $1.37 \mathrm{~km}$. Regarding the direction of dispersal, results concur with those of Smitley et al. (2008) in that no obvious pattern was observed with respect to cardinal direction (Figure 1). Further investigations should focus on the role of other factors including topography, prevailing winds, and vegetative cover in shaping patterns of emerald ash borer movement.

Findings indicated the leading edge of EAB advanced $1 \mathrm{~km}$ on average with a maximum distance of $1.37 \mathrm{~km}$, are in agreement with those of Haack and Petrice (2003) who reported a maximum dispersal distance of $1.5 \mathrm{~km}$ for EAB. The reason estimates for the current study are somewhat greater than those generated by McCullough et al. (2004) are likely related to disparities in the relative availability of hosts found in the two studies. McCullough et al. (2004) studied movement of EAB from a central location to surrounding ash trees in a forest comprised of native trees that included hundreds of ash. As beetles emerged from infested logs and dispersed, they readily encountered and colonized suitable hosts. Most beetles colonized trees within $100 \mathrm{~m}$ of their point of emergence. In Maryland, EAB had little opportunity to colonize ash proximate to the infested nursery for the following reasons. Subsequent to the initial detection of EAB in Maryland in August 2003 , more than 1,000 ash trees were removed within a circular $0.8 \mathrm{~km}$ eradication zone around the nursery. Beetles emerging from any ash tree that escaped the initial eradication attempt faced a relatively long flight to locate a suitable host. Moreover, if the initial eradication attempt in 2003 or subsequent attempts in 2006 and 2007 were completely successful, then the only possibility for detections other than a relatively small number of sentinel trees planted within the eradication zone would have been infestations generated by beetles that escaped expanding eradication buffers of $0.8 \mathrm{~km}$ per year. Finally, the analysis provides a liberal estimate of EAB movement. In 2006, only four foci were detected and included in the analysis. However, in 2007 and 2008 only the foci at the leading edge of the infestation and most distant from the nursery were included in the data set. Excluding infestations near the nursery likely inflates the estimate of the average advancement of the leading edge; however, it does not

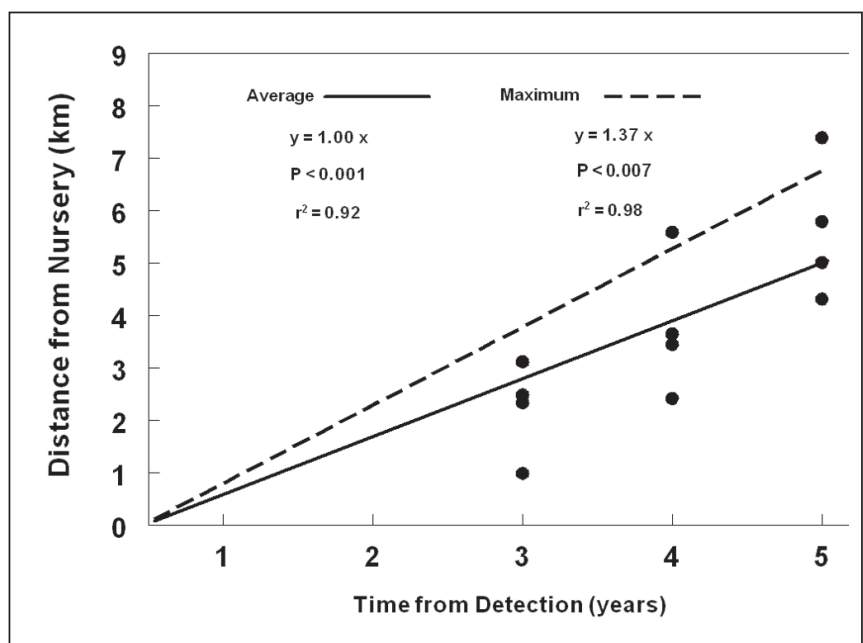

Figure 2. Rates of spread of emerald ash border in kilometers from time of initial detection in 2003. Average rate of spread of the leading edge (solid line) was based on the four most distant grid cells with EAB detections for each year in 2006, 2007, and 2008. Maximum rate of spread (dashed line) was based on the single most distant grid cell with an EAB detection in each year. Fitted lines are linear least square regressions.

affect the estimate for the maximum rate of spread. It is suggested that the maximum rate of spread is the more informative of the two estimates in assisting planning decisions by urban foresters.

These results provide insight into the relative merits of an aggressive quarantine and eradication program for EAB. Siegert et al. (2008) estimated the spread of EAB in southeastern Michigan to be $6.5 \mathrm{~km}$ each year during the initial phase of infestation. Smitley et al. (2008) estimated the rate of spread of canopy thinning to be $10.6 \mathrm{~km}$ each year. They suggested that combinations of natural aerial dispersal by the beetle and anthropogenic dispersal enabled by transport of ash trees or, more importantly, infested firewood or wood products underlie the rapid spread of EAB in southern Michigan. They warn that this trend is likely to continue throughout the Midwestern United States. The study authors were unable to exclude the possibility that human-assisted dispersal via the transport of trees, firewood, or wood products was responsible for some of the movement detected in EAB in our study. However, we believe that the concentration of detections in relatively close proximity to the initial site of infestation and the rather uniform annual rate of spread are consistent with the notion of aerial dispersal as a primary mode of movement by the beetle. It is entirely possible that eradication and educational activities in Maryland reduced the rate of spread of EAB many-fold compared to other locations where such efforts were not attempted or feasible. Finally, a caveat for future attempts at eradication programs for EAB: if destruction of hosts is considered, the eradication zone must exceed the $0.8 \mathrm{~km}$ employed in the Maryland infestation.

Acknowledgments. Support for this project was provided by the USDAAPHIS-PPQ Center for Plant Health Science and Technology. We thank Eric Rebek for comments to a previous draft of this manuscript and suggestions made by two anonymous reviewers. 


\section{LITERATURE CITED}

Cappaert, D., D.C. McCullough, T.M. Poland, and N.W. Siegert. 2005. Emerald ash borer in North America: A research and regulatory challenge. American Entomologist 51:152-165.

Gandhi, K.J.K., and D.A. Herms. 2010. Direct and indirect effects of alien insect herbivores on ecological processes and interactions in forests of eastern North America. Biological Invasions. 12:389-405.

Haack, R.A., and T.R. Petrice. 2004. Emerald ash borer adult dispersal. In: V. Mastro and R. Reardon (Eds.). Proceeding of the Emerald Ash Borer Research and Technology Development Meeting. FHTET-2004-02, USDA USFS APHIS, Morgantown, WV.

McCullough, D.G., T. Poland, and D. Cappaert. 2004. Dispersal of emerald ash borer: a case study at Tipton, Michigan. In Mastro, V., and R. Reardon (Eds.). Proceeding of the Emerald Ash Borer Research and Technology Development Meeting. FHTET-2004-02. USDA USFS APHIS, Morgantown, WV.

Raupp, M.J., A. Buckelew Cumming, and E.C. Raupp. 2006. Street tree diversity in Eastern North America and its potential for tree loss to exotic pests. Journal of Arboriculture \& Urban Forestry 32:297-304.

Siegert, N.W., D.G. McCullough, A.M. Liebhold, and F.W. Telewski. 2008. Dendrochronological reconstruction of the establishment and spread of emerald ash borer. In: V. Mastro, D. Lance, R. Reardon, and G. Parra (Eds.). Proceeding of the Emerald Ash Borer and Asian Longhorned Beetle Research and Technology Development Meeting. FHTET-2008-07. USDA USFS APHIS, Morgantown, WV.

Smitley, D., T. Davis, and E. Rebek. 2008. Progression of ash canopy thinning and dieback outward from the initial infestation of emerald ash borer (Coleoptera: Buprestidae) in Southeast Michigan. Journal of Economic Entomology 101:1643-1650.

Systat 11 Software. 2004. Cranes Software International Ltd., Chicago, IL.

Taylor, R.A.J., L.S. Bauer, D.L. Miller, and R.A. Haack. 2005. Emerald ash borer flight potential. In Mastro, V., and R. Reardon (Eds.). Proceeding of the Emerald Ash Borer Research and Technology Development Meeting. FHTET-2004-15. USDA USFS APHIS, Morgantown, WV.

Taylor, R.A.J., T.M. Poland, L.S. Bauer, K.N. Windell, and J.L. Kautz. 2007. Emerald ash borer flight estimates revised. In: V. Mastro, D. Lance, R. Reardon, and G. Parra (Eds.). Proceeding of the Emerald Ash Borer and Asian Longhorned Beetle Research and Technology Development Meeting. FHTET-2007-04. USDA USFS APHIS, Morgantown, WV.

Chris Sargent (corresponding author)

Department of Entomology

University of Maryland

College Park, MD 20742, U.S.A.

csargen1@umd.edu

Michael Raupp

Department of Entomology

University of Maryland

College Park, MD 20742, U.S.A.

mraupp@umd.edu
Dick Bean

Maryland Department of Agriculture

50 Harry S. Truman Parkway

Annapolis, MD 21401, U.S.A.

beanra@mda.state.md.us

\author{
Alan J. Sawyer \\ USDA-APHIS-PPQ-CPHST \\ Otis Laboratory \\ 1398 West Truck Road \\ Buzzards Bay, MA 02542-1329, U.S.A. \\ Alan.J.Sawyer@aphis.usda.gov
}

Résumé. L'agrile du frêne (Agrilus planipennis) est l'un des insectes parasites parmi les plus destructeurs des arbres urbains aux Etats-Unis. L'objectif de cette étude était de déterminer le degré de dissémination de l'agrile du frêne dans une zone de quarantaine où des tactiques d'interventions agressives telle que la destruction ont été employées. Des données historiques provenant du Département d'agriculture du Maryland ont été examinées pour les années 2003, 2006, 2007 et 2008 afin d'évaluer le degré de dissémination de l'agrile du frêne dans la zone de quarantaine du Maryland. En dépit des attentes envers l'éradication et l'éducation du public, l'agrile du frêne a persisté et la pointe de l'avancée de l'agrile s'est déplacée du point central de l'infestation à raison d'une distance moyenne de $1 \mathrm{~km}$ par an et une distance annuelle maximale de $1,37 \mathrm{~km}$ entre 2003 et 2008. Cet article présente une discussion des limites et des mérites relatifs de la quarantaine et du programme d'éradication et propose des suggestions pour la gestion future de l'agrile frêne.

Zusammenfassung. Der Eschenprachtkäfer ist einer der stärksten Pflanzenschädlinge an Stadtbäumen in den USA. Es war das Ziel der gegenwärtigen Studie, die Verbreitungsrate des Käfers innerhalb einer Quarantänezone, wo aggeressiv Bäume zerstört wurden, zu bestimmen. Wir untersuchten die historischen Daten des Maryland Dept. of Agriculture der Jahre 2003, 2006, 2007 und 2008, um die Ausbreitung innerhalb der Quarantänezonen zu bestimmen. Trotz aller Versuche der Ausrottung und der Öffentlichkeitsarbeit, blieb der Eschenprachtkäfer und die äußerste Verbreitungslinie verlängerte sich vom Punkt der zentralen Infektion um durchschnittlich $1 \mathrm{~km}$ pro Jahr und mit einer maximalen Rate von 1,37 km zwischen 2003 und 2008. Die Studie diskutiert die relativen Vor- und Nachteile dieser Quarantäne und der Ausrottungsprogramme und gibt Hinweise für künftige Kontrollmaßnahmen.

Resumen. El barrenador del fresno (Agrilus planipennis) (EAB, por sus siglas en inglés) es una de las plagas más destructivas de árboles urbanos en los Estados Unidos. El objetivo del estudio fue determinar la tasa de dispersión de EAB en una zona bajo cuarentena donde ocurrieron tácticas de intervención agresiva tales como la destrucción de los árboles. Fueron examinados registros históricos del Departamento de Agricultura de Maryland para los años 2003, 2006, 2007 y 2008, para determinar la tasa de dispersión de EAB en Maryland, Estados Unidos, dentro de la zona de cuarentena. A pesar de los intentos de erradicación y educación al público, EAB persistió, y la frontera más importante de los escarabajos se movió del centro de infestación a una tasa promedio anual de $1 \mathrm{~km}$ por año y una máxima de $1.37 \mathrm{~km}$ por año entre 20035 2008. Este reporte discute los méritos relativos y las limitaciones de este programa de cuarentena y erradicación y hace sugerencias para manejo futuro de EAB. 